\title{
Csoba J., Sipos F. (szerk.) (2021): Co-creation a közszolgáltatások modernizációjában \\ Lokális szolgáltatásfejlesztési kísérletek a közös alkotás módszerével (Debreceni Egyetemi Kiadó, p. 237)
}

\author{
RÁCZ KATALIN
}

\begin{abstract}
RÁCZ Katalin: kutatási igazgató, vezető szakértő, AKI Agrárközgazdasági Intézet, Fenntarthatósági Kutatások Igazgatóság; 1093 Budapest, Zsil u. 3-5.; racz.katalin@aki.gov.hu; https://orcid.org/ 0000-0003-2286-4793

Katalin RÁCZ: director of research, lead expert, Sustainability Research Directorate, Institute for Agricultural Economics AKI; Zsil u. 3-5., H-1093 Budapest, Hungary; racz.katalin@aki.gov.hu; https://orcid.org/ 0000-0003-2286-4793
\end{abstract}

A hazai társadalomtudományok területén átfogó, interdiszciplináris megközelítésű tanulmánykötet jelent meg a közelmúltban Csoba Judit és Sipos Flórián szerkesztésében. A Co-creation a közszolgáltatások modernizációjában - Lokális szolgáltatásfejlesztési kísérletek a közös alkotás módszerével címü, e-könyv formájában ${ }^{1}$ elérhető tanulmánykötet alapját a 2017-2021 között megvalósított Co-Creation of Public Service Innovation in Europe (CoSIE) címü projekt adta. A CoSIE projekt megközelítése szerint fenntartható közszolgáltatási innovációk a szolgáltatók és a szolgáltatások kedvezményezettjei közötti együttmüködések, partnerségek létrehozásával érhetőek el. Ebből kiindulva a tíz résztvevő országban ${ }^{2}$ a kutatóintézetekből, egyetemekből és a helyi fejlesztésben közreműködő szakmai szervezetekből álló konzorcium az alulról építkező, partneri viszonyt kialakító, a közszolgáltatások demokratikus megújitását célul tüző innovatív modellek kialakítására és támogatására vállalkozott.

A hazai és külföldi szerzők írásait tartalmazó tanulmánykötet fó célkitűzése, hogy a CoSIE projekt pilot programjainak tanulságain keresztül bemutassa és értelmezze a közszolgáltatások modernizációjának, valamint a közös alkotás (co-creation) szemléletének és módszerének alkalmazási lehetőségeit és korlátait. E célkitüzés különösen aktuális napjainkban, amikor a közszolgáltatások szervezőinek összetett társadalmi kihívásokkal, új szükségletekkel és körülményekkel kell megbirkózniuk, amelyek egyre kevésbé kezelhetők a hagyományos döntéshozatali folyamatokkal és szolgáltatásszervezési megoldásokkal.

A szerkesztők a kötetben szereplő tizenegy tanulmányt két nagyobb szerkezeti egységbe tagolták. Az első blokkban (I. A Co-creation módszer és a közszolgáltatások modernizációja: nemzetközi kitekintés) hazai és nemzetközi szerzők négy tanulmánya mutatja be a „közös alkotás” módszerének sajátosságait és alkalmazásának kritériumait. A kötet második részében (II. Kihivások és lokális válaszlehetőségek. Kísérlet a lokális gazdaság fejlesztését szolgáló közszolgáltatási modell kialakitására

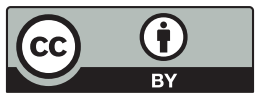


Magyarországon) szereplő hét tanulmány a hazai pilot programok környezetének, keretfeltételeinek, lebonyolításának, eredményeinek és hatásainak bemutatására vállalkozik.

A kötet Csoba Judit és Sipos Flórián által jegyzett első tanulmánya a közszolgáltatások modernizációjának elméleti kereteit mutatja be. A szerzők az időben változó közszolgáltatási modellek vizsgálata alapján arra jutnak, hogy megkérdöjelezhető a közszolgáltatások modernizációjának egyenesvonalú fejlődési íve. Valójában ugyanis az egyes országokban uralkodó hatalmi, politikai struktúrától függően egyre inkább hibrid közszolgáltatási modellek jönnek létre, amelyekben egyszerre érvényesülnek a bürokratikus (public administration), a piaci elvek (New Public Management) szerint müködő, valamint az állampolgárok aktív részvételére építő (post-New Public Management) modellek, és a lineáris fejlődés helyett inkább stagnáló, de akár a modernizációs folyamattal ellentétes irányú tendenciák is mutatkoznak. A tanulmány külön érdeme, hogy az olvasó számára világos áttekintést ad az ezredfordulót követően érvényesülő közszolgáltatásfejlesztési modellekről azok központi céljai és módszerei alapján.

A tanulmánykötet második, Chris Fox, Harri Jalonen, Susan Baines, Andrea Bassi, Veronica Moretti és Michael Willoughby által jegyzett, terjedelmében és tartalmában is nagylélegzetű tanulmánya a co-creation fogalmának kialakulását, a társfogalmakkal való párhuzamosságokat és különbségeket, a közös alkotási módszer alkalmazásának előnyeit és árnyoldalait, valamint az alkalmazásával együtt járó hatások mérésével kapcsolatos kérdéseket tárgyalja. A szerzők abból indulnak ki, hogy a közszektor innovációjának legjobb módját az együttműködő partnerségek létrehozása jelenti a szolgáltatást nyújtók (közszektorbeli szereplők, harmadik szektorbeli szervezetek, magáncégek) és a szolgáltatások közvetlen és közvetett kedvezményezettjei között. Megközelítésükben a szolgáltatásnyújtás voltaképpen egy társadalmi konstrukciós folyamatot jelent, amelyben az önszerveződő rendszerek szereplői közösen alkudják ki a szabályokat és az intézményi kereteket. A folyamat, amelyben az állampolgárok különböző csoportjai és a közszolgáltatásokban érintettek együtt alkotnak meg új közszolgáltatásokat, hosszú távú társadalmi befektetésnek is tekinthető, amely az állam szerepének újraértelmezéséhez vezethet, elősegítve a demokratikus megújulást és a társadalmi befogadást.

A kötet következő tanulmánya (melynek szerzői Chris Fox, Susan Baines, Rob Wilson, Mike Martin, Riccardo Prandini, Andrea Bassi, Giulia Ganugi, Harri Jalonen és Rob Gründemann) rávilágít arra, hogy a közös alkotás módszerének hozadékát nem elsősorban az állami kiadások csökkentése jelenti, sokkal inkább a társadalmi szükségletek, rétegigények jobb kielégítése. A szerzők kifejtik, hogy a CoSIE projekt megvalósítása során a kísérleti projektek résztvevőit sokkal inkább a közös alkotás morális vonatkozásai inspirálták, semmint a várható hatékonyság, hatásosság. A projektekben résztvevők a közös alkotást különösen a marginalizálódott, hatalommal nem bíró emberek iránti társadalmi igazságosság szempontjából tartották jelentősnek és hasznosnak. A szerzők arra is rámutatnak, 
hogy a közös alkotás nem csupán a végfelhasználók (fogyasztók) részéről igényel új szemléletet, az együtt alkotott, kontextusfüggő, erőforrásalapú szolgáltatások kialakítása és fenntartása a közszolgáltatások területén dolgozók részéről is adaptív, befogadó megközelítést, új képességeket, kompetenciákat, működtetési mechanizmusokat tesz szükségessé.

A kötet negyedik tanulmányában a szerzők (Chris Fox, Susan Baines, Rob Wilson, Harri Jalonen, Inga Narbutaite Aflaki, Riccardo Prandini, Andrea Bassi, Giulia Ganugi és Heli Arami-Immonen) az előző tanulmányoknál elmélyültebben vizsgálják a technológia szerepét a szolgáltatásfejlesztési folyamatban. Ez különösen hangsúlyos kérdés napjainkban, hiszen, noha a digitális technológiákkal szemben erőteljesek a várakozások a szolgáltatásfejlesztés minden területén, valójában nagyon kevés kézzelfogható információval rendelkezünk arról, hogy a digitális technológiák képesek-e előmozdítani a közszolgáltatásokhoz való jobb hozzáférést vagy akár a szolgáltatások minőségi fejlődését. A jövőbeni közszolgáltatásfejlesztések szempontjából elgondolkodtató, hogy a digitális kirekesztődés több CoSIE pilot projektben egyelőre inkább nehezítő tényezőként jelentkezett, és a közös alkotás folyamatát sok esetben behatárolta. A tanulmány fontos megállapítása, hogy a digitális irányítás vagy az e-kormányzás önmagában nem ad választ a közszolgáltatások fejlesztésének minden problémájára, a közszolgáltatások modernizációjának alapját sokkal inkább a szolgáltatók és az állampolgárok közötti interakciók elmélyítése képezi, történjen az közvetlen vagy virtuális találkozások során.

Általánosságban elmondható, hogy az első blokkban szereplő tanulmányok elméleti megalapozottsága imponálóan elmélyült, a szerzők a közszolgáltatások modernizációját társadalomelméleti kontextusba ágyazottan, a hazai környezetben egyelőre kevéssé ismert szakirodalmakra alapozva értelmezik. Az elméleti érvelések befogadását a szövegdobozokban bemutatott CoSIE pilotok segíti elö, amelyek alátámasztják, hogy a közös alkotás valójában a társadalmi innováció egyik megjelenési formájaként is értelmezhető. Az első szerkezeti egységbe tagolt tanulmányok világossá teszik, hogy a "közös alkotás" túlmutat a közszolgáltatások reformján, segítségével olyan makroszintü problémák is mérsékelhetőek, mint a demokratikus deficit vagy a társadalmi befogadás terén mutatkozó egyenlőtlenségek.

A kötet második blokkjában elhelyezett tanulmányok arról adnak képet, hogy milyen eszközökkel, feltételekkel és eredményekkel lehet egy alulról szerveződő, új közszolgáltatási modell kereteit megteremteni Magyarország vidéki térségeinek kistelepülésein. Más megfogalmazásban, a hazai tapasztalatokat összegző tanulmányok voltaképpen arra a kérdésre adnak a választ, hogy a "co-creation" módszer milyen kilátásokkal alkalmazható Magyarországon a közszolgáltatások modernizációjában és a helyi fejlesztésben. Kulcsfontosságú válaszokat tartogat a tanulmánykötet a helyi fejlesztésben érintettek számára, figyelembe véve azt a körülményt, hogy a társadalmi felzárkóztatás területén alkalmazott hagyományos fejlesztéspolitikai megoldások Magyarország számos leszakadó, szegregálódó településén zsákutcába jutottak, megújításra szorulnak. 
A második blokk Csoba Judit és Sipos Flórián által jegyzett felvezető tanulmánya rámutat arra, hogy a hazai környezetben a közszolgáltatások modernizációjának mozgatórugóját nem csak az időben változó szükségletek jelentik, hanem a passzív ellátásokra alapozott központi források folyamatos szűkülése is. A folyamat eredményeképpen a településeknek egyre inkább magunknak kell feltárniuk, mely szükségletek azok, amelyek helyben, önállóan, részben saját forrásokra alapozva kielégíthetők. A források szűkülése a közszolgáltató önkormányzatokat szelektív diszkrecionális elvek érvényesítésére készteti, ami lényegében azt jelenti, hogy egyre inkább a legrászorultabbak részére biztosítanak krízisjellegű juttatásokat. A szerzők felhívják a figyelmet arra, hogy e sajátos, hiányon alapuló rendszer fenntartásához a magyar településszerkezet és az erre épülő önkormányzati rendszer is nagymértékben hozzájárul. A "modernizációs" folyamatban jellemzően azok az önkormányzatok járnak jól, amelyek a méretgazdaságosság elve alapján több fogyasztót tudnak ellátni a közszolgáltatásokkal, a kistelepülések pedig fokozatosan leépítik, elveszítik hagyományos közszolgáltatási funkcióikat. Mindeközben gyökeresen átalakulnak az önkormányzatok közszolgáltatási feladatai: a hagyományos közszolgáltatási funkciók (oktatás, egészségügy, szociális ellátás stb.) egyre inkább háttérbe szorulnak, ugyanakkor a közpolitikában törvényeken, rendeleteken keresztül az önkormányzatokkal szemben új elvárások fogalmazódnak meg (pl. gazdaságszervezési, piacszervezési feladatok, jövedelemtermelő faluvállalatként való működés).

A kötet következő tanulmányában Csoba Judit és Sipos Flórián a hazai környezetben még kevéssé ismert co-creation fogalmának és módszertanának szociális szolgáltatásfejlesztés kontextusában történő tisztázását követően átfogó képet ad a Magyarország négy hátrányos helyzetű megyéjéből (Szabolcs-Szatmár-Bereg, Nógrád, Borsod-Abaúj-Zemplén és Jász-Nagykun-Szolnok) kiválasztott tíz kistelepülésen ${ }^{3}$ megvalósított szolgáltatásfejlesztési projektekről. A tanulmányban a szerzők áttekintést adnak a Magyarország rurális térségeiben korábban megvalósult, számos vonatkozásban a co-creation módszer elveit alkalmazó, így a CoSIE pilotokhoz megfelelő kiindulási alapot adó lokális gazdaságfejlesztési kezdeményezésről, a szociális földprogramról. A tanulmány mindemellett a CoSIE pilot projektek konkrét céljait, a fejlesztés különböző szintjeit, a pilot programokban résztvevő települési kört és a projektekben bevonásra került háztartások legfontosabb jellemzőit is bemutatja.

A tanulmánykötet következő, Sipos Flórián által jegyzett tanulmánya a szemléletformálás elméleti keretrendszerét, a fejlesztés különböző szintjeit és szakaszait mutatja be, alátámasztva, hogy a megvalósult kísérleti projektekben a közös alkotási és szolgáltatástervezési folyamat mögött minden esetben átgondolt fejlesztési módszerek és beavatkozások álltak. A tanulmányból kiderül, hogy a közös alkotás módszertanát elsajátító résztvevők (településvezetők, helyi fejlesztésben közreműködők, lakosság) nem elsősorban gazdasági jellegü projektcélokat fogalmaztak meg, sokkal inkább olyan, nagyobb horderejü, komplex társadalmi célokat, mint a településük közösségének életben tartása, a vidéki életstílus felélesztése és népszerűsítése, a tele- 
pülés népességmegtartó erejének növelése, a környezeti fenntarthatóság elvének érvényesítése a helyben megtermelt élelmiszerek és a helyben nyújtott szolgáltatások keretében.

Nagyné Varga Ilona, Szabó Beáta és Szarvák Aranka tanulmányában a kísérleti projektek elindításának körülményeiről, a terepenként differenciált tartalmú szakmai tevekénységekről és az elért eredményekről kaphatunk képet. A beavatkozások részletes, kronologikus sorrendben történő bemutatása nemcsak a közös alkotás módszertanának megismerését teszi lehetővé az olvasó számára, hanem a teljes folyamatot végigkísérő értékelés módszertanába is betekintést nyújt. A hatásvizsgálat konkrét lehetőségeiről és korlátairól részletesebben Csoba Judit tanulmányából tájékozódhatunk. Az alkalmazott értékelési módszer innovatív eleme, hogy módszertanának kidolgozásába és az értékelési folyamat megvalósításába valamennyi célcsoportot bevonták (az „,együttműködésen alapuló értékelés”, „közös értékelés” keretében). A közös alkotás során a kutatók számára korábban „megfigyelési objektumként" létező résztvevők maguk is társkutatókká váltak, részt vettek a „megfigyelésben”, a kutatásban és a folyamatok értékelésében. Részben ennek is köszönhető, hogy a megvalósítási folyamatban való részvétel olyan pozitív eredményekkel járt, mint a résztvevők növekvő motivációja, új együttmüködések kialakítása, új szerepek elsajátítása, a lokális demokrácia erősödése.

A lokális gazdaság megerősítésére irányuló közszolgáltatási modell esélyeit és korlátait bemutató, Csoba Judit és Sipos Flórián által jegyzett következő tanulmányból azonban az is világossá válik, hogy az alulról építkező, saját erőforrásokra alapozó közszolgáltatási modell kiépítése a pilot településeken kihívást jelentett. Ehhez hozzájárult az a körülmény, hogy az elmúlt évtizedekben az érintett települések jelentősebb önkormányzati vagyon, saját forrás (pl. helyi adóbevételek) hiányában a működés, fejlesztés tekintetében szinte kizárólag külső, zömmel redisztributív pályázati erőforrásokra támaszkodhattak, erősödő adminisztratív és anyagi függőségi keretrendszerben. Ezzel összefüggésben a projektben résztvevő települések mindegyikén feladatként jelentkezett a korábbi forrásszerzési minták, paternalista mechanizmusok lebontása, a helyi erőforrásalapú fejlesztési módszerek és az aktív részvételi formák elsajátítása. A tanulmányban megosztott tapasztalatok az olvasó számára világossá teszik, hogy a struktúraváltás időigényes, lassú folyamat, erre utal, hogy a résztvevők és a szakértők között fennálló hatalmi aszimmetria a többéves projektidőszak alatt sem volt teljes mértékben kiiktatható.

A második blokk utolsó tanulmányából - melynek szerzői Maszlag Fanni, Ladancsik Tibor és Csoba Judit - kirajzolódik, hogy a tíz településen megvalósított kísérleti projektek nem csupán a lokális gazdaság erősítésére szolgáló, közösen formált közszolgáltatási modell kialakítását segítették elő, hanem az együttélés szabályozásának, a „közös müködésnek” is meghatározó elemeivé váltak. A co-creation elvre építő szolgáltatási rendszer meghonosítása mellett a kísérleti projektek fontos eredménye a résztvevők kapcsolathálójának erősödése, kiszélesedése, a 
demokratikus müködési formák elsajátítása és alkalmazása. A fejlesztés mérföldköveit az olvasó maga is nyomon követheti, amelyet az tesz lehetővé, hogy a szerkesztők a projekt keretében készült közösségi riporter videók ${ }^{4}$ megjelenítéséről is gondoskodtak, melyeket az olvasó a kötet digitális mellékleteként érhet el.

A kötet tanulmányai a közös alkotáson alapuló szolgáltatásfejlesztés lehetséges eszközeiről, folyamatáról, lépéseiről, a nyomon követésre lehetőséget adó értékelés hátteréről olyan részletezettségű áttekintést adnak, melyek ismeretében az olvasó nem kizárólag a közszolgáltatások fejlesztéséhez kap fogódzót, hanem a közös alkotás módszerének egyéb területeken (pl. a fejlesztéspolitika részterületeit érintő döntéstámogatás) történő alkalmazásához is. Kihívást jelent, hogy a közös alkotás módszerének elfogadása és alkalmazása mikro-, mezo- és makroszinten egyaránt mélyreható, szemléletbeli változásokat és jól előkészített tanulási, felkészülési folyamatot feltételez. A közszolgáltatások modernizációjához új szemléletre, mentalitásváltásra van szükség, amely új tudáselemek, kapcsolatok és munkamegosztás, a hierarchiák helyett hálózatokon alapuló szervezeti struktúra és irányítási modell (kísérleti szemléletü irányítás/experimentalist governance) kialakítását igényli. Ez lényegében azt is jelenti, hogy az ehhez szükséges szervezeti, szakmai, pénzügyi keretek megteremtése, a közös alkotáson alapuló közszolgáltatási modell kialakítása politikai támogatottságot feltételez.

Összefoglalóan elmondható, hogy a tanulmánykötet szemléletében és tematikájában is hiánypótló mü Magyarországon. A kötetben szereplő tanulmányok fogódzót adnak a köz- és szakpolitika formálói számára a közszolgáltatások modernizációját elősegítő megoldási javaslatok, szakpolitikai stratégiák kialakításához. Mindemellett a tanulmánykötet felsőoktatási tananyagként (pl. jogász- és szociológusképzésben, a szociálpolitikus- és szociálismunkás-képzésben), és a közszolgáltatási területen dolgozók képzésében is hasznosulhat, de fogódzót adhat a helyi fejlesztésben és a közszolgáltatások szervezésében, müködtetésében résztvevők számára, beleértve a közszolgáltatások potenciális igénybevevőit, az állampolgárokat.

\section{Jegyzetek}

1 https://dea.lib.unideb.hu/dea/static/pdf_viewer/pdf.js/web/viewer.htmlf=MzIxNTIOL2Nzb2J hX3NpcG9zX2NvY3JlYXRpb24ucGRmP3NlcXVlbmNlPTEmaXNBbGxvd2VkPXk=

2 A CoSIE projekt résztvevő országaiban (Egyesült Királyság, Észtország, Finnország, Görögország, Hollandia, Lengyelország, Magyarország, Olaszország, Spanyolország, Svédország) a résztvevők különböző célcsoportokat és a közszolgáltatási modell keretében megoldandó, eltérő problématerületeket érintő tíz különböző közszolgáltatás megújítását, vagy új közszolgáltatási formák kialakítását célzó modellkísérleti programot valósítottak meg.

3 Panyola (Szabolcs-Szatmár-Bereg megye), Tomor (Borsod-Abaúj-Zemplén megye), Magyargéc, Piliny, Sóshartyán (Nógrád megye), Besenyszög, Kőtelek, Kunszentmárton, Tiszaörs, Jászladány (Jász-Nagykun-Szolnok megye).

4 A közösségi riporter videókészítés módszertanát a projektbe épített képzés keretében sajátították el a célcsoport tagjai, majd folyamatosan. dokumentálták a közös alkotás folyamatát. 